Iqrar, I. bioRXiv

\title{
Bioactivity-driven high throughput screening of microbiomes of medicinal plants for discovering new biological control agents
}

Irum Iqrar $^{1}$, Zabta Khan Shinwari ${ }^{1}$, Ashraf El-Sayed ${ }^{2}$ and Gul Shad Ali ${ }^{3 *}$

${ }^{3}$ Mid-Florida Research and Education Center and Department of Plant Pathology, University of Florida/Institute of Food and Agricultural Sciences, 2725 Binion Rd, Apopka, FL 32703

${ }^{1}$ Department of Biotechnology, Quaid-i-Azam University Islamabad, Pakistan

${ }^{2}$ Enzymology and Fungal Biotechnology Lab (EFBL),

Microbiology and Botany Department, Faculty of Science, Zagazig University, Egypt

*Corresponding author: Gul Shad Ali

Email address: gsali@ufl.edu

Tel: +1-407-410-6933

Fax: +1-407-814-6186 
Iqrar, I. bioRXiv

\section{ABSTRACT}

In a preliminary DNA-based microbiome studies, diverse culturable and unculturable bacterial taxa were identified in the roots and rhizospheres of different medicinal plants. In this report, culturable endophytic bacteria were isolated from four economically important medicinal plants Dodonaea viscosa, Fagonia indica, Caralluma tuberculata and Calendula arvensis. On the basis of initial antimicrobial screening, nine bacterial species in seven different genera, Streptomyces, Pseudomonas, Enterobacter, Bacillus, Pantoea, Pseudarthrobacter and Delftia, were selected for further analyses. These bacteria were identified using 16S rRNA gene sequencing. Antimicrobial assays of these selected bacteria revealed that Pseudomonas taiwanensis has strong anti-Phytophthora activity. Volatiles produced by $P$. taiwanensis inhibited growth of $P$. parasitica more than $80 \%$. Ethyl acetate extracts of $S$. alboniger MOSEL-RD3, P. taiwanensis MOSEL-RD23, E. hormaechei MOSEL-FLS1 and B. tequilensis MOSEL-FLS3 and D. lacustris MB322 also displayed high potency against $P$. parasitica. All these bacterial extracts showed strong inhibition against $P$. parasitica at different concentrations $(4 \mu \mathrm{g} / \mathrm{mL}-400 \mu \mathrm{g} / \mathrm{mL})$. Bacterial extracts showing higher bioactivity ( $>80 \%$ inhibition in vitro) were selected for detached-leaf assay against P. parasitica on tobacco. In detached-leaf assay, application of 1\% ethyl acetate bacterial extract of MOSE L-RD3, MOSEL-RD23, MOSEL-FLS1, MOSEL-FLS3 and MB322 reduced lesion sizes and lesion frequencies caused by $P$. parasitica by 68 to $81 \%$. Over all $P$. taiwenensis MOSEL-RD23 showed positive activities for all the assays. Analysing the potential of bacterial endophytes as biological control agents can potentially lead to the formulation of broad-spectrum biopesticides for sustainable production of crops.

Keywords: Endophytic Bacteria, Medicinal plants, Biocontrol Agents, Phytophthora, HPLC 


\section{Introduction}

Infectious diseases caused by phytopathogens pose a great threat to food production and stability of ecosystem worldwide [1]. Among the well-recognized plant pathogens, Phytophthora spp. are the most destructive Oomycetes, including more than 100 species [2]. Phytophthora parasitica is a soil borne pathogen with a wide range of host plants [3]. The severity of $P$. parasitica assumed to the feasibility of zoospores dispersal, infecting plant roots and leaves and rapidly germinating via formation of appressorium at the tip of germ tube [4]. Isolates of $P$. parasitica are capable of infecting a numerous plant species, causing mainly black shank to tobacco as a common worldwide disease [4].

Over the years, biological control of plant pathogens has gained importance because it offers ecological and environmental friendly alternatives for controlling crop diseases [5]. Biocontrol against plant diseases is not only an alternative to chemical pesticides, but it may also provide control of diseases that cannot be managed (or only partly) by other control strategies [6]. The use of beneficial microorganisms (biocontrol agents) is considered as one of the most promising methods for rational and safe agronomical practices. Most of the bacterial strains exploited as biocontrol agents belong to the genera Agrobacterium, Pseudomonas and Bacillus [7] [8]

Bacteria can also thrive as endophytes in various plants and plant parts and have to be adapted to the specific plant environment, which they colonize and therefore, the metabolic potential of endophytes is likely to differ from their soil dwelling counterparts [9]. Endophytes offer a wide range of benefits to plants by promoting growth via direct and indirect mechanisms [10], direct mechanism such as the production and regulation of levels of phytohormones, including indole3 -acetic acid and ethylene $[11,12]$, whereas indirect mechanism involve decreased disease severity [13], inducing plant defense mechanisms by the production of toxic compounds (antibiosis) in the host plant; producing substances with antifungal and antibacterial activity [14, 15]. Commercial applications of bacterial endophytes are inoculants in agriculture [16] and a source of secondary metabolites for medical applications [17].

An important mechanism of biological control involves the production of secondary metabolites by these endophytes. Endophytes are less explored for their metabolic potential [9]. Many endophytes are members of genera Pseudomonas, Burkholderia and Bacillus [18], and these 
genera are well known for the diverse range of secondary bioactive metabolic products [19].

These secondary metabolites with antagonistic activities have been identified as HCN, phenazines of which major ones are phenazines-1-carboxylic acid and phenazine-1-

1 carboxymide, 2,4-diacetyl phloroglucinol, pyrrolnitrin, Zwittermycin A and kanosamine. Cyclic compounds are also known for their antagonistic activities [20]. Plants produce several classes of phytohormones including auxins, cytokinins, brassinosteroids, gibberellins, abscisic acid, ethylene, jasmonates and strigolactones playing roles in development and stress responses.

The main objectives of this study were to 1) screen potential bacterial endophytes isolated from Dodonaea viscosa, Fagonia indica, Caralluma tuberculata and Calendula arvensis for their bioactivity against plant pathogens, 2) extract and assay diffusible and volatile antimicrobial compounds from a select set of endophytes against Phytophthora parasitica, and, 3) conduct preliminary fractionation of the bioactive metabolites from a select set of endophytes using High Performance Liquid Chromatography.

\section{Materials and methods}

\section{Molecular identification and $16 \mathrm{~S}$ biodiversity analysis}

Endophytic bacteria were isolated from four different medicinal plants i.e. Dodonaea viscosa, Fagonia indica, Caralluma tuberculata and Calendula arvensis. Information about the biological control agents used in this study is summarised in Table 1. Endophytic bacteria were identified using 16S rRNA gene sequencing [21].

\section{In vitro antimicrobial activity of bacteria against Phytophthora parasitica}

Phytophthora parasitica, which infects a variety of ornamental, vegetable and citrus [22] was used as target plant pathogen for evaluating the antimicrobial activity of the recovered bacterial endophytes. Dual-culture growth inhibition assays were conducted in petri dishes as follows:A $0.5 \mathrm{~cm}$ diameter mycelial plug from 5 days old $P$. parasitica culture was placed in the middle of V8 medium, and incubated for $48 \mathrm{~h}$ at $25^{\circ} \mathrm{C}$. A $10 \mu \mathrm{l}$ cell suspension $\left(10^{5} \mathrm{CFU} / \mathrm{mL}\right)$ of potential biocontrol bacteria was inoculated at three spots located $3 \mathrm{~cm}$ away from the center of Phytophthora plugs. Plates were re-incubated at $25^{\circ} \mathrm{C}$ for 5 days, and growth inhibition zones of Phytophthora were measured. 


\section{Effects of volatiles on the growth of Phytophthora parasitica}

To investigate the effect of volatiles produced by bacterial endophytes on the growth of the $P$. parasitica bipartite petri dishes were used. Bacterial isolates were inoculated into one compartment of the bipartite petri dish containing TSB media, while $P$. parasitica was placed in the other compartment containing V8 media, and plates were tightly sealed with the parafilm and incubated at $25^{\circ} \mathrm{C}[23]$.

\section{Extraction of extracellular secondary metabolites from endophytic bacteria}

Selected bacterial strains were inoculated into $10 \mathrm{ml} \mathrm{TSB}$ (Oxoid) and incubated for $24 \mathrm{~h}$ at $30{ }^{\circ} \mathrm{C}$ with shaking until the optical density $\left(\mathrm{OD}_{600}\right)$ reached approximately $0.8-1$. The culture broth was transferred to $500 \mathrm{~mL}$ TSB contained in a $1 \mathrm{~L}$ flask and incubated at $30^{\circ} \mathrm{C}$ in a shaker incubator $(220 \mathrm{rpm})$ for $72 \mathrm{~h}$. At this point, all cultures grew to early stationary phase $\left(\mathrm{OD}_{600}=\right.$ 3.0). Bacterial culture was transferred to falcon tubes and cells were pelleted by centrifugation at $8,000 \times g$ for $20 \mathrm{~min}$ at room temperature. The supernatant was filtered through a $0.20-\mu \mathrm{m}$ filter and extracted with an equal volume of ethyl acetate as described previously [24] with some modifications. The solvent was then evaporated through vacufuge at $45^{\circ} \mathrm{C}$ to get the crude extract of bioactive metabolites. The extract was then dissolved in $50 \mathrm{~mL}$ methanol.

\section{In vitro antimicrobial activity of bacterial extract}

Antimicrobial activity of crude extracts of the selected endophytic bacteria was determined using the disc diffusion method [25]. Sterile filter paper discs were placed approximately $1 \mathrm{~cm}$ away from the growing edge of a 24-hr old $P$. parasitica culture on V8 plates. Discs were saturated with each bacterial extract; Methanol was used as a negative control.

\section{6-well plate antimicrobial assay of bacterial extract}

In vitro, $P$. parasitica growth inhibition assay was performed in $96-$ well microtiter. Bacterial crude extracts were diluted appropriately $2 \%$ to $0.02 \%$ in $100 \mu 1$ sterile water. To each well, 100 $\mu l$ of freshly prepared $P$. parasitica zoospore suspension $\left(10^{5}\right.$ zoospores $\left./ \mathrm{mL}\right)$ were added to each well. Each treatment was replicated three times, and each experiment was repeated at least two times. Plates were wrapped with parafilm and incubated at $25^{\circ} \mathrm{C}$ under continuous light for 18 hrs. Phytophthora growth was quantified using a rapid rasazurine assay (Fai and Grant, 2009, 
Chromophere 74:1165). At the end of the 18-hr incubation period, $10 \mu \mathrm{L}$ of a $10 \%$ resazurin (Alamar Blue, Cat\# DAL1025, Invitrogen) solution was added to each well. Plates were incubated for another 4 hours and the absorbance of the plate was read at 560 and $590 \mathrm{~nm}$ wavelength with the Synergy H1 hybrid multimode plate reader (BioTek).

\section{Bioactivity-driven fractionation of bacterial extracts using HPLC}

Fractionation was performed using HPLC according to a method described previously [26]. Chromatographic separation of metabolites was conducted using C18 column using mobile phases A (water with $0.1 \%$ formic acid) and B (acetonitrile with $0.1 \%$ formic acid) at a flow rate of $0.4 \mathrm{~mL} / \mathrm{min}$. HPLC profile consisted of an initial gradient composition $(95 \% \mathrm{~A}, / 5 \% \mathrm{~B})$ held for $1 \mathrm{~min}$, increased to $20 \% \mathrm{~B}$ over the next $5 \mathrm{~min}$, increased to $80 \%$ B over the next $10 \mathrm{~min}$, increased to $100 \% \mathrm{~B}$ over the next $10 \mathrm{~min}$, and held at $100 \% \mathrm{~B}$ for $2 \mathrm{~min}$. For reuse, the initial gradient composition (95\% A, /5\% B) was restored and allowed to equilibrate for $5 \mathrm{~min}$. The absorption spectrum of fractions was determined in the UV-visible region (230-800 nm) using Synergy H1 Hybrid Multimode spectrophotometer (BioTek). For in vitro anti-phytophthora activity of fractions, growth inhibition assay was performed with a $2 \%$ final concentration of each fraction in microtiter plates using the rasazurine assay as described above.

\section{Detached-leaf Phytophthora parasitica inhibition assays}

The efficacy of bacterial extracts was assessed in a detached leaf assay as described previously [25]. Healthy leaves of tobacco plants from greenhouse-grown were immersed in 15\% Chlorox for $2 \mathrm{~s}$ and immediately rinsed with sterile water three times. Leaves were blot dried lightly and arranged randomly on two layers of moist Whatman filter papers in humid chambers. Each leaf was inoculated with three treatments: 1) Bacterial extract and $P$. parasitica together, 2) methanol \& P. parasitica (control) and 3) V8 \& P. parasitica (control).

\section{Results}

\section{Isolation and Molecular Identification of Bacterial Endophytes}

A number of different bacteria were isolated from four different medicinal plants i.e. Dodonaea viscosa, Fagonia indica, Caralluma tuberculata and Calendula arvensis. On the basis of initial screening assays including cell wall degrading enzymes, siderophore production and antifungal 
assays, a total of 9 bacteria were selected for further analysis. Based on 16S rRNA gene sequencing, these bacterial isolates were classified into Actinobacteria, Proteobacteria and Firmicutes in nine different genera i.e. Streptomyces, Pseudomonas, Enterobacter, Bacillus, Pantoea, Pseudarthrobacter and Delftia. Details of nucleotide BLAST searches of these endophytic bacteria are provided in Table 1. Endophytic bacterial isolates with $100 \%$ nucleotide identity to known bacterial species were MOSEL-RD3, MOSEL-RD23 and MOSEL-RD36 from D. viscosa, MOSEL-FLS1 and MOSEL-FLS3 from F. indica, and MOSEL-MIC5 and MOSELMIS12 from C. tuberculata. Isolates MOSEL-FIL19 from $F$. indica and MB322 from $C$. arvensis showed $95 \%$ and $93.6 \%$ nucleotide identity to Pantoea sp. and Delftia lacustris, respectively.

\section{Screening of endophytic bacteria against $P$. parasitica}

Antimicrobial activity of selected bacterial isolates was evaluated against $P$. parasitica in vitro. Visual comparison of assay plates to control plates showed clear growth inhibition by several endophytes as is shown in Figure 1A. Among all the selected isolates, Pseudomonas taiwanensis MOSEL-RD23 showed the highest (55\%) activity against $P$. parasitica (Fig. 1A and B). Delftia lacustris MB322 and Streptomyces alboniger MOSEL-RD3 also showed inhibition but to a lesser extent. The remaining isolates showed no or very little activity.

\section{Effect of volatiles on the growth of $\boldsymbol{P}$. parasitica}

Visual assessment of initial screening assays revealed that several endophytes slowed growth of Phytophthora without showing a clear growth inhibition zone. This observation suggested that these endophytes might be emitting volatile compounds that are inhibitory to Phytophtora. To test this hypothesis, we conducted bipartite split-plate growth inhibition assays, in which Phytophthora was physically separated from potential antimicrobial endophytes but was otherwise exposed to gaseous antimicrobial compounds emitted by endophytes. These assays showed that the growth of the $P$. parsitica was significantly inhibited in the presence of several bacterial strains. A majority of bacteria showed growth inhibition at varying levels ranging from about 50 to $80 \%$ reduction as compared to control (Fig. 2A \& B). Pseudomonas taiwnensis MOSEL-RD23, Bacillus flexus MOSEL-MIC5 and Streptomyces alboniger MOSEL-RD3 were the most effective, displaying 50 - 60\% growth inhibition. The remaining isolates, 
Pseudarthrobacter phenanthrenivorans MOSEL-MIS12, Enterobacter hormaechei MOSELFLS1, Bacillus tequilensis MOSEL-FLS3, Pantoea sp. MOSEL-FIL19 Delftia lacustris MB322 and Pseudomonas geniculata MOSEL-RD36 showed some activity resulting in less than 50\% reduction in mycelial growth as compared to the control.

\section{Assaying extracellular secondary metabolites for inhibiting growth of $P$. parasitica}

Bioactivity of ethyl acetate extract from endophytic bacteria culture supernatant was assessed using the disc diffusion method against $P$. parasitica. Bacterial extracts of $S$. alboniger MOSELRD3, P. taiwanensis MOSEL-RD23, Delftia lacustris MB322, E. hormaechei MOSEL-FLS1 and B. tequilensis MOSEL-FLS3 showed very strong activity against $P$. parasitica (Fig. 3A). The remaining isolates showed no or very little activity. These bacteria displayed more or less similar growth inhibition ranging from 40 to $45 \%$ (Figure $3 \mathrm{~B}$ ). The rest of the isolates were less effective displaying 20 to $30 \%$ growth inhibition. Microscopic examination of the growth inhibition zones showed reduced and scattered mycelial growth compared to growth on control plates (Fig. 3B). Zone of inhibition was measured in terms of growth inhibition normalized to growth on control plates (Fig. 3C).

Bioactivity of the ethyl acetate extract of the culture supernatants from endophytic bacteria against $P$. parasitica was assessed at different concentrations using resazurin-based antimicrobial assays in microtiter plates. Ethyl acetate extracts dissolved in methanol were tested using three 10 -fold serial dilutions at $2 \%(400 \mu \mathrm{g} / \mathrm{ml}), 0.2 \%(40 \mu \mathrm{g} / \mathrm{ml})$ and $0.02 \%(4 \mu \mathrm{g} / \mathrm{ml})$. At the $2 \%$ concentration levels, extracts from all bacteria showed strong but mostly similar growth inhibition ( $>80 \%$ ) against $P$. parasitica. Similarly, at the $0.2 \%$ level, ethyl acetate extracts from all bacteria also showed growth inhibition. However, they differed significantly in the levels of inhibition with MOSEL-RD3, MB322, MOSEL-FLS1 and MOSEL-FLS3 showing strong (> 80\%) growth inhibition, whereas MOSEL-RD23, MOSEL-FIL19, MOSEL-MIC5 and MOSELMIS12 showing intermediate (approx. 50\%) inhibition. Inhibition assays with the lowest concentration $(0.02 \%)$ showed that the extracts of MB322 still displayed strong inhibition against $P$. parasitica (Table 1; Figure 4A). Micrographs of hyphae of P. Parasitica treated with the selected bacterial extracts showed abnormal growth compared to control (Figure 4B). Representative pictures showing convoluted, swollen nodes and abnormal growth of hyphae of $P$. parasitica in response to bacterial extracts are shown in Figure 4C. 


\section{Detached-leaf $P$. parasitica inhibition assays}

The in vivo anti-Phytophthora activity of bacterial extracts were determined using a tobacco detach leaf assay. In this assay, bacterial extracts of the selected bacterial strains were tested for preventing expansion of lesions caused by P. parasitica on tobacco leaves. As is shown in Figure 5A and 5B, all bacterial extracts inhibited expansion of lesions produced by $P$. parasitica on tobacco leaves as compared to negative controls, which consisted of methanol only plus $P$. parasitica or V8 plus $P$. parasitica. Tryphan blue staining of inoculated leaves showed that in the control treatments, Phytophthora had grown extensively beyond the inoculation spots. In contrast, very little growth was observed outside the spots treated with ethyl acetate bacterial extracts (Figure 5A). Quantification of lesion sizes showed an average of 50\% reduction by bacterial extracts compared to controls (Figure 5B). Overall, these results indicate that ethyl acetate extracts of these bacteria contain antimicrobial properties, which are active in vivo.

\section{Bioactivity-driven fractionation and UV-Vis scanning}

Preparative HPLC was used to fractionate culture filtrates for finding fractions with bioactivity. All fractions of each extract were assayed for their bioactivity against $P$. parasitica in vitro. These analyses showed variable bioactivity in multiple fractions (Figure 6). Although, none of the fractions of any of the bacteria stood out as the sole source of anti-Phytophthora activity, in general, MB322 and MOSEL-FLS1 exhibited a trend of increasingly stronger activity in fractions with longer retention times. In contrast, MOSEL-RD3 displayed stronger activity in fractions with early retention time points, starting at $7 \mathrm{~min}$, which then displayed a declining trend towards the end of the run. Mosel-RD23 did not reveal a defined trend of antiPhytophthora activity with almost all fractions showing strong activity except a few fractions in the middle of the run, which showed very little activity. MOSEL-FLS3 displayed very different but a well-defined trend with fractions with retention times between 15 to 27 minutes displaying a normal distribution. These differential results show that the tested isolates most likely have antimicrobial compounds with different biochemical properties. Most fractions that displayed strong activity also caused different abnormal growth patterns such as convoluted hyphae, swollen nodes, and constricted and excessive branching, suggesting that inhibition of $P$. parasitica is associated with effect on different cellular and physiological processes. 
In order to determine the absorbance properties of bacterial extracts, fractions of two bacterial isolates, MOSEL-FLS1 and MOSEL-FLS3, which displayed different HPLC-determined antimicrobial patterns, were subjected to UV-Vis spectral scanning at $230-1000 \mathrm{~nm}$. These analyses revealed that different fractions of both bacterial isolates contained compounds with strong absorbance in the 230 to $290 \mathrm{~nm}$ range (Figure S3). However, consistent UV-Vis patterns with any significant correlation with the HPLC-based inhibition patterns were not observed. These results further suggested that antimicrobial compounds in different fractions of different bacteria have different physicochemical properties. 


\section{Discussion}

Medicinal plants usually grow vigorously in the wild without any significant irrigation, and fertilizer and pesticides inputs. Association with beneficial microbes is considered as one of the major contributors to the enhanced growth of these medicinal plants [27]. However, microbiomes of medicinal plants are less explored. Medicinal plants used in this study are wellknown for their therapeutic potential. Dodonaea viscosa is an evergreen, woody and wild shrub growing throughout the tropics. It is found in sub-tropical regions and is known for its medicinal value [28]. Fagonia indica is a small spiny shrub with reputed medicinal value and is distributed in the warm and dried areas of the middle east and the Indian subcontinent [29, 30]. Calendula arvensis, commonly known as Field Marigold, is an annual herb, which is naturally distributed in Southern Europe, Iran, Afghanistan and Pakistan and is known for various ethnic medicinal properties [31,32]. Caralluma tuberculata is a herbaceous, succulent and leafless plant, which is naturally found in the dry areas of Africa, South Mediterranean and tropical Asia and it is also known for several medicinal properties $[33,34]$. Similar to many medicinal plants, the microbiome of these plants is also not known. In this report we investigated several endophytic bacteria isolated from these plants for anti-Phytophthora activities.

Initial characterization of bacteria isolated from these four plants showed that several of them produce cell wall degrading enzymes and siderophores, which have previously been associated with plant growth promotion and antimicrobial activities (ref). Endophytic bacteria isolated from these plants were explored for their potential as biocontrol agents. Streptomyces alboniger, Pseudomonas taiwanensis and Pseudomonas geniculata from Dodonaea viscosa, which were previously reported as potential plant growth promoting bacteria [21]. Enterobacter hormaechei and Bacillus subtilis has been suggested to play a role in the therapeutic properties of Fagonia indica [35]. Bacillus flexus and Pseudarthrobacter phenanthrenivorans, Delftia and Baciluus tequilis, which all displayed very potencies, are not widely studied for their biological control potential especially against Phytophthora disease. Genome of type strain of Pseudarthrobacter phenanthrenivorans Sphe3, which was isolated from a creosote-polluted site in Greece has been sequenced [36]. Similarly, genome of another strain, isolated from arseniccontaminated soil in China has also been sequenced [37]. Sequence annotation of these strains revealed genes involved in pollution detoxification and tolerance particularly against arsenate 
and several metals[36, 37]. They are, however, not investigated extensively for their antimicrobial activity. Nevertheless, genes associated with the synthesis and regulation of several polypeptides have been reported, some of which might be involved in the antiPhytophthora activity of the isolate reported here [36, 37]. Whether or not the strain reported in this study contain genes for and metabolic pathways for production of compounds and enzymes that might be involved in inhibiting the growth of Phytophthora remains to be investigated. We have planned on sequencing the genome of the isolate of Pseudarthrobacter phenanthrenivorans reported in this study, which will provided clues about its mode of action. Since Pseudarthrobacter phenanthrenivorans isolates have not been studied extensively or commercialized as biological control agents, genome information and anti-Phytophthora studies reported here will be useful in the development of this strain into a commercial biopesticide. A new biological control agent with anti-Phytophthora activity will provide disease management tool for organic production of crops by suppressing soil-borne Phytophthora, which are important plant pathogens causing significant economic and yield losses in a wide range of crops [38].

In this report, we screened the above-mentioned bacteria for their potential application in the biological control of Phytophthora diseases. In in vitro growth inhibition assays, Pseudomonas taiwanensis MOSEL-RD23 exhibited the highest antifungal activity against $P$. parasitica. Azotobacter sp., Pseudomonas sp., Streptomyces sp. and Bacillus sp. have previously been reported for antifungal activity [39]. These bacterial endophytes help in plant growth promotion and in control of pathogens. Positive effects displayed by bacterial endophytes are mediated by several metabolites acting together [9]. Similar to previous studies, bacterial extracts of biocontrol agents reported in this study also induced abnormal growth in the hyphae of $P$. parasitica. These anomalies are most likely due to compounds that negatively affect hyphal growth [40].

Diffusible and volatile compounds both showed activity against Phytophthora suggesting that the biological control agents reported in this study employ various modes of actions. Bioactivity-driven fractionation of ethyl acetate extracts of endophytic bacteria using HPLC analyses showed anti-Phytophthora activity is not restricted to a specific fraction. Strikingly, almost all fractions showed activity against Phytophthora suggesting that antimicrobial 
Iqrar, I. bioRXiv

compounds responsible for controlling Phytophthora contain different physical and chemical properties. This is also consistent with previous reports where different compounds such as lytic peptides, antibiotics and other secondary metabolites contribute to overall biocontrol activity of these biocontrol agents (reviewed in [41]). These extracts might have soluble and volatile compounds, which, in future studies will be further characterized using LC-MS/MS. These future studies could potentially result in the identification of compounds with different modes of actions, which could be utilized in formulating synthetic blends of biocontrol agents for optimal plant growth promotion and disease suppression.

\section{Conclusions}

This is the first report about the biological activities of secondary metabolites as biocontrol agents.

\section{Acknowledgements}

This work was supported by funding from Higher Education Commission of Pakistan to I.I. and by the National Institute of Food and Agriculture - United States Department of Agriculture (Accession number 1017239 and FL-APO-005155) to G.A. 


\section{Literature cited}

1. Compant S, Duffy B, Nowak J, Clément C, Barka EA. Use of plant growth-promoting bacteria for biocontrol of plant diseases: principles, mechanisms of action, and future prospects. Applied and environmental microbiology. 2005;71(9):4951-9.

2. Kroon LP, Brouwer H, de Cock AW, Govers F. The genus Phytophthora anno 2012. Phytopathology. 2012;102(4):348-64. Epub 2011/12/22. doi: 10.1094/PHYTO-01-11-0025. PubMed PMID: 22185336.

3. Meng Y, Zhang Q, Ding W, Shan W. Phytophthora parasitica: a model oomycete plant pathogen. Mycology. 2014;5(2):43-51.

4. Wang Y, Meng Y, Zhang M, Tong X, Wang Q, Sun Y, et al. Infection of Arabidopsis thaliana by Phytophthora parasitica and identification of variation in host specificity. Mol Plant Pathol. 2011;12(2):187-201. Epub 2011/01/05. doi: 10.1111/j.1364-3703.2010.00659.x. PubMed PMID: 21199568.

5. Ongena M, Jacques P. Bacillus lipopeptides: versatile weapons for plant disease biocontrol. Trends in microbiology. 2008;16(3):115-25.

6. Cook RJ. Making greater use of introduced microorganisms for biological control of plant pathogens. Annual review of phytopathology. 1993;31(1):53-80.

7. Fravel D. Commercialization and implementation of biocontrol 1. Annu Rev Phytopathol. 2005;43:337-59.

8. Dagdas YF, Belhaj K, Maqbool A, Chaparro-Garcia A, Pandey P, Petre B, et al. An effector of the Irish potato famine pathogen antagonizes a host autophagy cargo receptor. Elife. 2016;5. doi: 10.7554/eLife.10856. PubMed PMID: 26765567; PubMed Central PMCID: PMCPMC4775223.

9. Brader G, Compant S, Mitter B, Trognitz F, Sessitsch A. Metabolic potential of endophytic bacteria. Current Opinion in Biotechnology. 2014;27:30-7.

10. Yau JA, Diánez F, Marín F, Carretero F, Santos M. Screening and evaluation of potential biocontrol fungi and bacteria foliar endophytes against Phytophthora capsici and Phytophthora parasitica on pepper. J Food Agric Environ. 2013;11:490-5.

11. Kang SH, Cho H, Cheong H, Ryu C-M, Kim JF, Park S-H. Two bacterial entophytes eliciting both plant growth promotion and plant defense on pepper (Capsicum annuum L.). Journal of microbiology and biotechnology. 2007;17(1):96.

12. Hardoim PR, van Overbeek LS, van Elsas JD. Properties of bacterial endophytes and their proposed role in plant growth. Trends in microbiology. 2008;16(10):463-71.

13. Senthilkumar M, Govindasamy V, Annapurna K. Role of antibiosis in suppression of charcoal rot disease by soybean endophyte Paenibacillus sp. HKA-15. Current microbiology. 2007;55(1):25-9. 
14. Wang H, Wen K, Zhao X, Wang X, Li A, Hong H. The inhibitory activity of endophytic Bacillus sp. strain CHM1 against plant pathogenic fungi and its plant growth-promoting effect. Crop protection. 2009;28(8):634-9.

15. $\mathrm{Hu} \mathrm{HQ}, \mathrm{Li} \mathrm{XS}, \mathrm{He} \mathrm{H}$. Characterization of an antimicrobial material from a newly isolated Bacillus amyloliquefaciens from mangrove for biocontrol of Capsicum bacterial wilt. Biological control. 2010;54(3):359-65.

16. Sturz A, Nowak J. Endophytic communities of rhizobacteria and the strategies required to create yield enhancing associations with crops. Applied soil ecology. 2000;15(2):183-90.

17. Strobel G. Plant-Associated Microorganisms (Endophytes) as a new source of bioactive natural products. Medicinal Plant Biotechnology: From Basic Research to Industrial Applications. 2007:49-72.

18. Lodewyckx C, Vangronsveld J, Porteous F, Moore ER, Taghavi S, Mezgeay M, et al. Endophytic bacteria and their potential applications. Critical Reviews in Plant Sciences. 2002;21(6):583-606.

19. Ryan RP, Germaine K, Franks A, Ryan DJ, Dowling DN. Bacterial endophytes: recent developments and applications. FEMS microbiology letters. 2008;278(1):1-9.

20. Ulloa-Ogaz A, Muñoz-Castellanos L, Nevárez-Moorillón G. Biocontrol of phytopathogens: antibiotic production as mechanism of control. The battle against microbial pathogens: basic science, technological advances and educational programes FORMATEX RESEARCH CENTER, Spain. 2015:305-9.

21. Afzal I, Iqrar I, Shinwari ZK, Yasmin A. Plant growth-promoting potential of endophytic bacteria isolated from roots of wild Dodonaea viscosa L. Plant Growth Regulation. 2017;81(3):399-408.

22. Patel JS, Vitoreli A, Palmateer AJ, El-Saycd A, Norman DJ, Goss EM, et al. Characterization of Phytophthora spp. Isolated from Ornamental Plants in Florida. Plant Dis. 2016;100(2):500-9. doi: 10.1094/Pdis-05-15-0598-Re. PubMed PMID: WOS:000370305300033.

23. Hunziker L, Bönisch D, Groenhagen U, Bailly A, Schulz S, Weisskopf L. Pseudomonas strains naturally associated with potato plants produce volatiles with high potential for inhibition of Phytophthora infestans. Applied and environmental microbiology. 2015;81(3):821-30.

24. Kjer J, Debbab A, Aly AH, Proksch P. Methods for isolation of marine-derived endophytic fungi and their bioactive secondary products. Nature protocols. 2010;5(3):479-90.

25. Ali GS, El-Sayed AS, Patel JS, Green KB, Ali M, Brennan M, et al. Ex Vivo Application of Secreted Metabolites Produced by Soil-Inhabiting Bacillus spp. Efficiently Controls Foliar Diseases Caused by Alternaria spp. Applied and environmental microbiology. 2016;82(2):47890 .

26. Kim WJ, Kim YO, Kim JH, Nam B-H, Kim D-G, An CM, et al. Liquid ChromatographyMass Spectrometry-Based Rapid Secondary-Metabolite Profiling of Marine Pseudoalteromonas sp. M2. Marine drugs. 2016;14(1):24. 
27. El-Sayed ASA, Akbar A, Iqrar I, Ali R, Norman D, Brennan M, et al. A glucanolytic Pseudomonas sp. associated with Smilax bona-nox L. displays strong activity against Phytophthora parasitica. Microbiol Res. 2018;207:140-52. Epub 2018/02/21. doi: 10.1016/j.micres.2017.11.018. PubMed PMID: 29458848.

28. Rajamanickam V, Rajasekaran A, Anandarajagopal K, Sridharan D, Selvakumar K, Rathinaraj BS. Anti-diarrheal activity of Dodonaea viscosa root extracts. Int J Pharm Bio Sci. 2010;1(4):182-5.

29. Anil P, Nikhil B, Manoj G, Prakash N. Phytochemicals and biological activities of Fagonia indica. Int Res J Pharm. 2012;3:56-9.

30. Waheed A, Barker J, Barton SJ, Owen CP, Ahmed S, Carew MA. A novel steroidal saponin glycoside from Fagonia indica induces cell-selective apoptosis or necrosis in cancer cells. European Journal of Pharmaceutical Sciences. 2012;47(2):464-73.

31. Heyn C, Joel A. Reproductive relationships between annual species ofCalendula (Compositae). Plant systematics and evolution. 1983;143(4):311-29.

32. Paolini J, Barboni T, Desjobert J-M, Djabou N, Muselli A, Costa J. Chemical composition, intraspecies variation and seasonal variation in essential oils of Calendula arvensis L. Biochemical Systematics and Ecology. 2010;38(5):865-74.

33. Ahmad B, Abbas SJ, Hussain F, Bashir S, Ahmad D. Study on Caralluma Tuberculata Nutritional Composition and Its Importance as Medicinal Plant. Pak J Bot. 2014;46(5):1677-84.

34. Bibi Y, Tabassum S, Zahara K, Bashir T, Haider S. Ethnomedicinal and pharmacological properties of Caralluma tuberculata NE Brown-A review. Pure and Applied Biology. 2015;4(4):503.

35. Rahman L, Shinwari ZK, Iqrar I, Rahman L, Tanveer F. An assessment on the role of endophytic microbes in the therapeutic potential of Fagonia indica. Annals of Clinical Microbiology and Antimicrobials. 2017;16(1):53. doi: 10.1186/s12941-017-0228-7.

36. Kallimanis A, Labutti KM, Lapidus A, Clum A, Lykidis A, Mavromatis K, et al. Complete genome sequence of Arthrobacter phenanthrenivorans type strain (Sphe3). Stand Genomic Sci. 2011;4(2):123-30. Epub 2011/06/17. doi: 10.4056/sigs.1393494. PubMed PMID: 21677849 ; PubMed Central PMCID: PMCPMC3111998.

37. Xu L, Shi W, Zeng XC, Yang Y, Zhou L, Mu Y, et al. Draft genome sequence of Arthrobacter sp. strain B6 isolated from the high-arsenic sediments in Datong Basin, China. Stand Genomic Sci. 2017;12:11. Epub 2017/02/01. doi: 10.1186/s40793-017-0231-9. PubMed PMID: 28138355; PubMed Central PMCID: PMCPMC5259909.

38. Panabieres F, Ali GS, Alagui MB, Dalio RJD, Gudmestad NC, Kuhn ML, et al. Phytophthora nicotianae diseases worldwide: new knowledge of a long-recognised pathogen. Phytopathologia Mediterranea. 2016;55(1):20-40. doi: 10.14601/Phytopathol_Mediterr-16423. PubMed PMID: WOS:000376104400002. 
Iqrar, I. bioRXiv

39. Ahmad F, Ahmad I, Khan M. Screening of free-living rhizospheric bacteria for their multiple plant growth promoting activities. Microbiological research. 2008;163(2):173-81.

40. Ali M, Kim B, Belfield KD, Norman D, Brennan M, Ali GS. Inhibition of Phytophthora parasitica and $\mathrm{P}$. capsici by silver nanoparticles synthesized using aqueous extract of Artemisia absinthium. Phytopathology. 2015;105(9):1183-90.

41. Ali GS, Norman D, El-Sayed AS. Soluble and Volatile Metabolites of Plant GrowthPromoting Rhizobacteria (PGPRs): Role and Practical Applications in Inhibiting Pathogens and Activating Induced Systemic Resistance (ISR). Adv Bot Res. 75: Academic Press; 2015. p. 24184. 


\section{Figure legends.}

Figure 1. Biological activity of endophytic bacteria against Phytophthora parasitica. (A) Representative pictures of plates showing effect of live bacteria on the growth of $P$. parasitica. (B) Bar graphs showing inhibition of P. parasitica by endophytic bacteria normalized to growth on control plates. Error bars represent S.E. of means.

Figure 2. Effect of volatiles produced by endophytic bacteria on the growth of Phytophthora parasitica. (A) Representative pictures showing effect of volatiles produced by endophytic bacteria on the growth of $P$. parasitica. (B) Bar graph showing \% normalized growth of $P$. parasitica as a result of production of volatiles by endophytic bacteria.

Figure 3. Bioactivity of ethyl acetate extract from endophytic bacteria culture supernatant showing inhibition against Phytophthora parasitica. (A) Bacterial extracts (MOSEL-w2, MOSEL-w7, MOSEL-w13, MB322, MOSEL-RD3, MOSEL-RD23, MOSEL-RD36, MOSELFLS1, MOSEL-FLS3 and MOSEL-FIL19) showing strong activity against $P$. parasitica. (B) Representative micrographs of bacterial extract showing inhibition of $P$. parasitica as compared to control at different magnification (7.5, 10 and 15) under compound microscope. (C) Bar graph showing growth inhibition of $P$. parasitica by bacterial extracts normalized to growth on plates

Figure 4. Bioactivity of the ethyl acetate extract from endophytic bacteria culture supernatant at different concentrations against Phytophthora parasitica. (A) Bacterial extracts showing \%inhibition of $P$. parasitica at different concentrations a) $400 \mu \mathrm{g} / \mathrm{ml} \mathrm{b)} 40 \mu \mathrm{g} / \mathrm{ml}$ and c) $4 \mu \mathrm{g} / \mathrm{ml}$. (B) Micrographs showing abnormal growth of hyphae of P. Parasitica in response to the different concentrations of bacterial extracts as compared to control. (C) Micrograph showing convoluted, swollen nodes and abnormal growth of hyphae of $P$. parasitica in response to bacterial extract

Figure 5. In vivo detached lead Bioactivity of $1 \%$ bacterial extracts against Phytophthora parasitica. (A) Detached leaf assay showing activity of bacterial extract of MOSEL-RD3, MOSEL-RD23, MOSEL-FLS1, MOSEL-FLS3 and MB322 on the growth of $P$. parasitica. Bar graphs showing average lesion diameter caused by $P$. parasitica on tobacco leaves 
Iqrar, I. bioRXiv

Figure 6. Bioactivity of fractions of the ethyl acetate extract from selected endophytic bacteria culture supernatant obtained through high-pressure liquid chromatography (HPLC) against $P$. parasitica 
Iqrar, I. bioRXiv

A

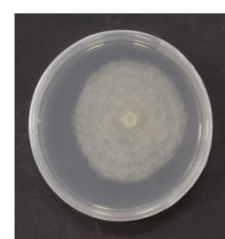

Control

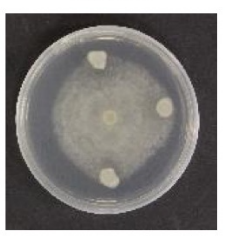

MOSEL-FLS1

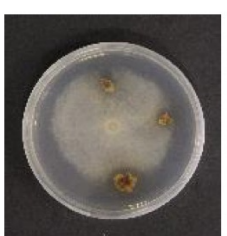

MOSEL-RD3

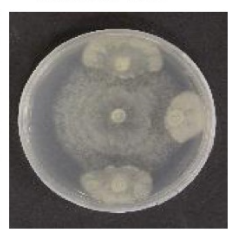

MOSEL-FLS3

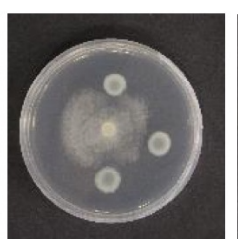

MOSEL-RD23

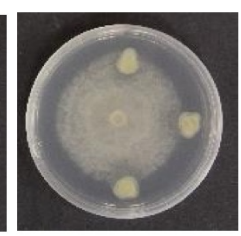

MOSEL-FIL19

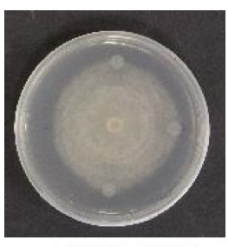

MOSEL-RD36

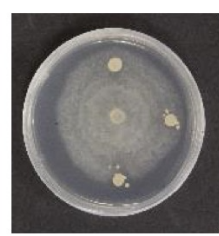

MOSEL-MIC5

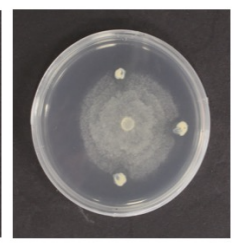

MB322

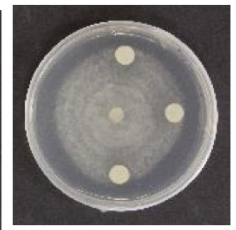

MOSEL-MIS12

B
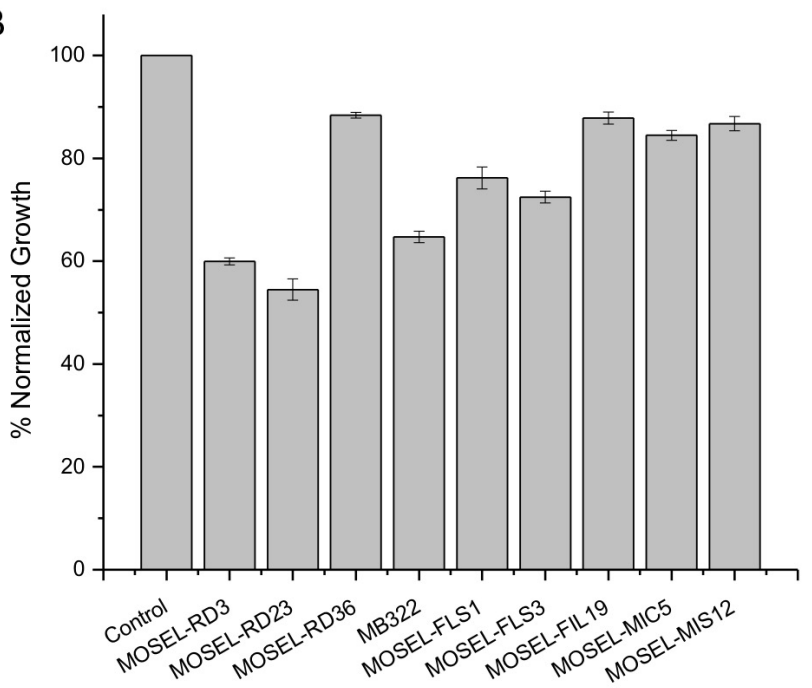

Bacterial Strains

Figure 1. Biological activity of endophytic bacteria against Phytophthora parasitica. (A) Representative pictures of plates showing effect of live bacteria on the growth of P. parasitica. (B) Bar graphs showing inhibition of $P$. parasitica by endophytic bacteria normalized to growth on control plates. Error bars represent S.E. of means. 
Iqrar, I. bioRXiv

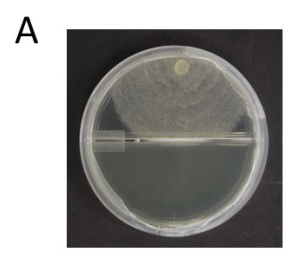

Control

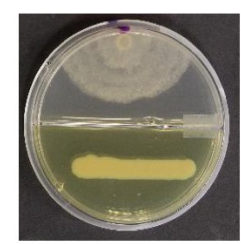

MOSEL-FLS1

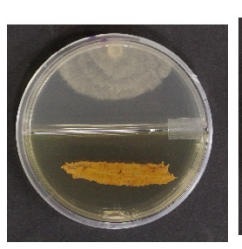

MOSEL-RD3

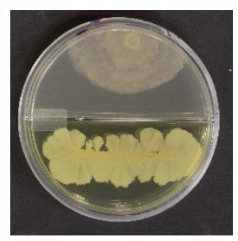

MOSELFLS3

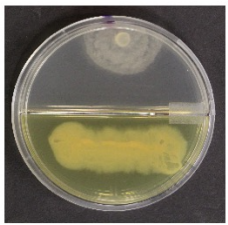

MOSEL-RD23

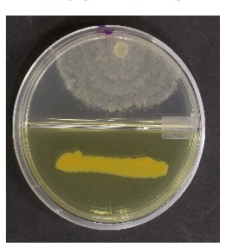

MOSEL-FIL19

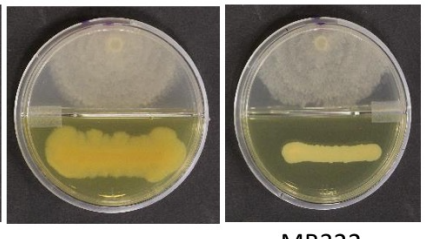

MB322

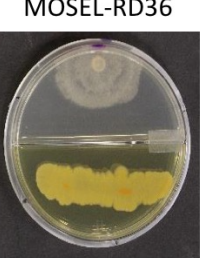

MOSEL-MIC5

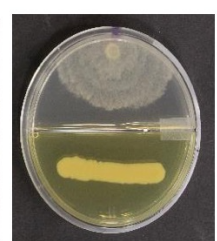

MOSEL-MIS12

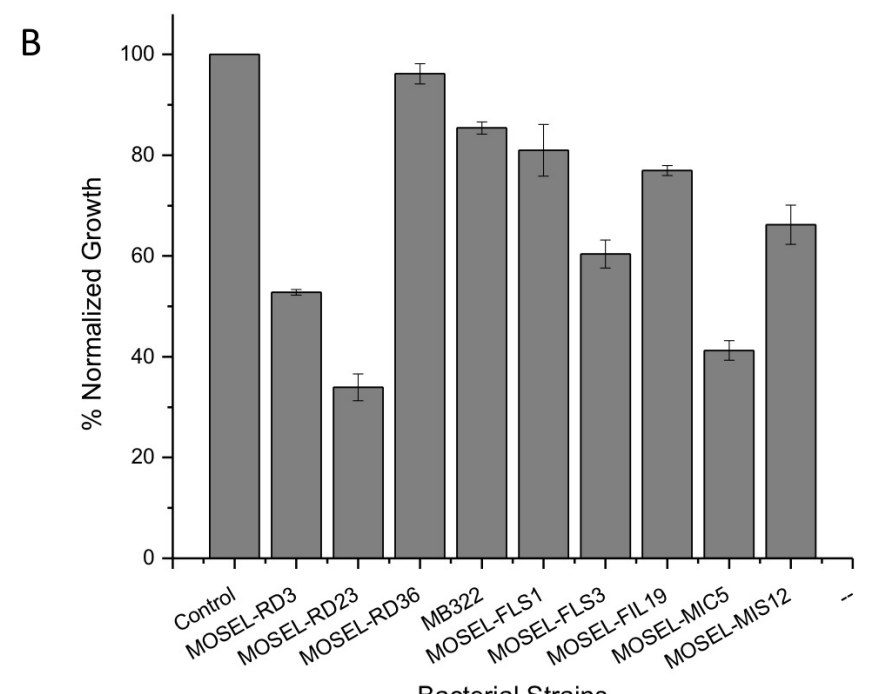

Bacterial Strains

Figure 2. Effect of volatiles produced by endophytic bacteria on the growth of Phytophthora parasitica. (A) Representative pictures showing effect of volatiles produced by endophytic bacteria on the growth of $P$. parasitica. (B) Bar graph showing \% normalized growth of $P$. parasitica as a result of production of volatiles by endophytic bacteria. 
A

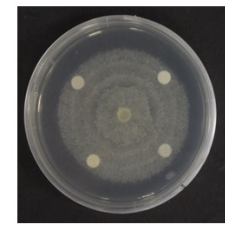

Control

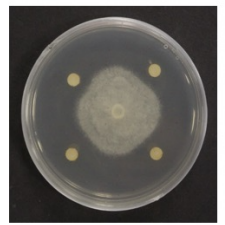

MOSEL-FLS1

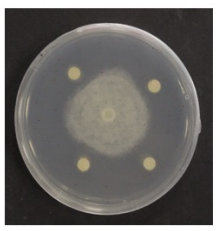

MOSEL-RD3

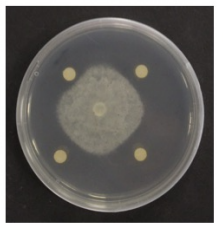

MOSEL-FLS3

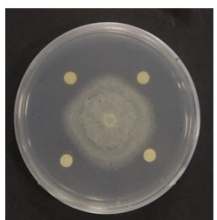

MOSEL-RD23

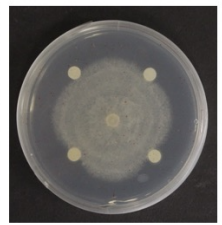

MOSEL-FIL19

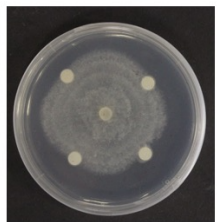

MOSEL-RD36

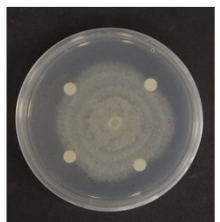

MOSEL-MIC5

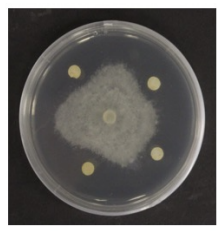

MB322

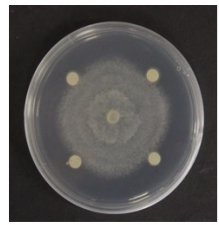

MOSEL-MIS12

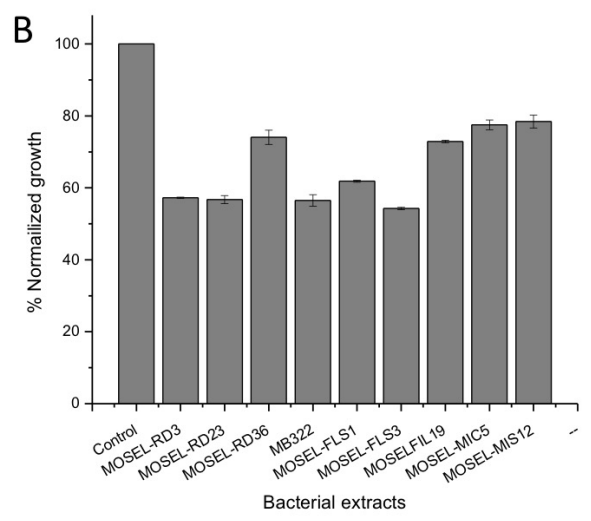

C

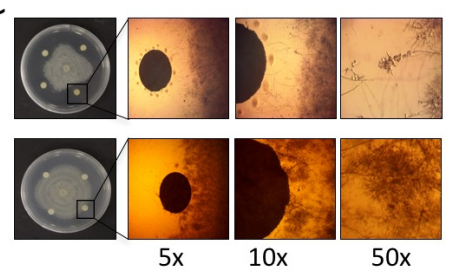

Figure 3. Bioactivity of ethyl acetate extract from endophytic bacteria culture supernatant showing inhibition against Phytophthora parasitica. (A) Bacterial extracts (MOSEL-w2, MOSEL-w7, MOSEL-w13, MB322, MOSEL-RD3, MOSEL-RD23, MOSEL-RD36, MOSELFLS1, MOSEL-FLS3 and MOSEL-FIL19) showing strong activity against $P$. parasitica. (B) Representative micrographs of bacterial extract showing inhibition of $P$. parasitica as compared to control at different magnification (7.5, 10 and 15) under compound microscope. (C) Bar graph showing growth inhibition of $P$. parasitica by bacterial extracts normalized to growth on plates 
Iqrar, I. bioRXiv

A

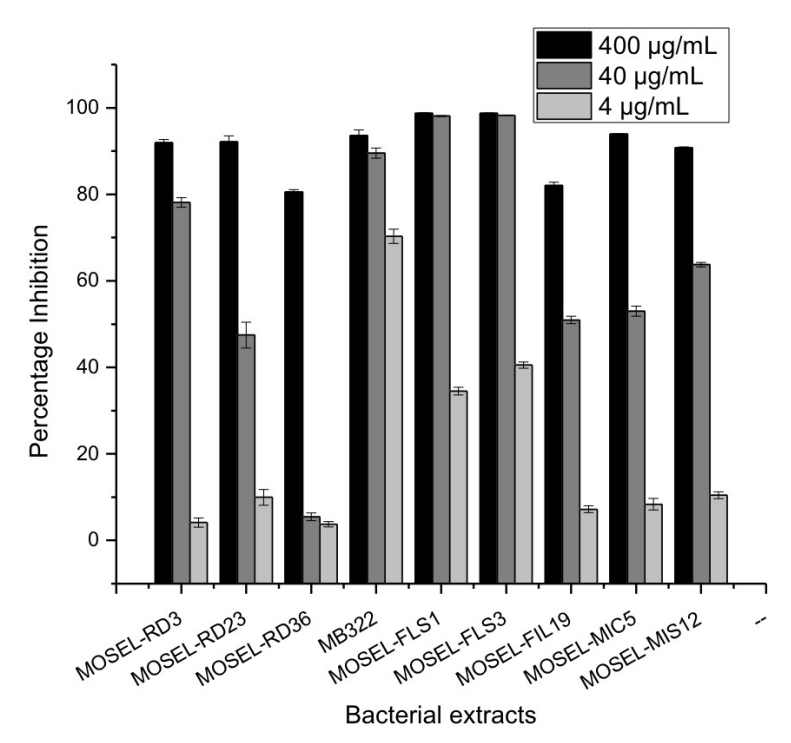

B

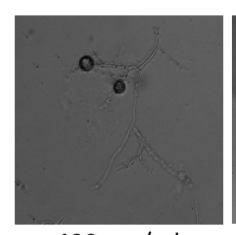

$400 \mathrm{mg} / \mathrm{ml}$

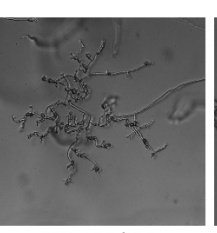

$40 \mathrm{mg} / \mathrm{ml}$

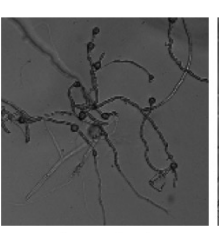

$4 \mathrm{mg} / \mathrm{ml}$

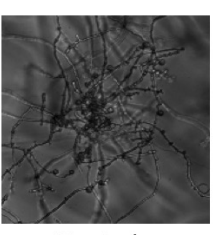

Control

C

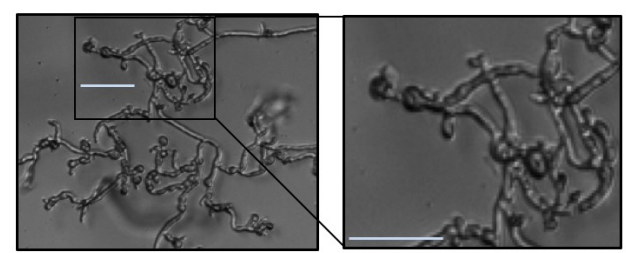

Figure 4. Bioactivity of the ethyl acetate extract from endophytic bacteria culture supernatant at different concentrations against Phytophthora parasitica. (A) Bacterial extracts showing \%inhibition of P. parasitica at different concentrations a) $400400 \mu \mathrm{g} / \mathrm{ml}$ b) $0.04400 \mu \mathrm{g} / \mathrm{ml}$ and $0.004400 \mu \mathrm{g} / \mathrm{ml}$. (B) Micrographs showing abnormal growth of hyphae of P. Parasitica in response to the different concentrations of bacterial extracts as compared to control. (C) Micrograph showing convoluted, swollen nodes and abnormal growth of hyphae of $P$. parasitica in response to bacterial extract 
Iqrar, I. bioRXiv

A
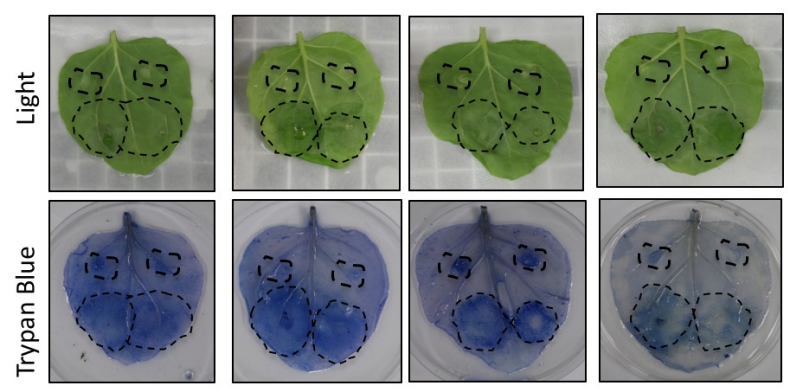

MOSEL-FLS3
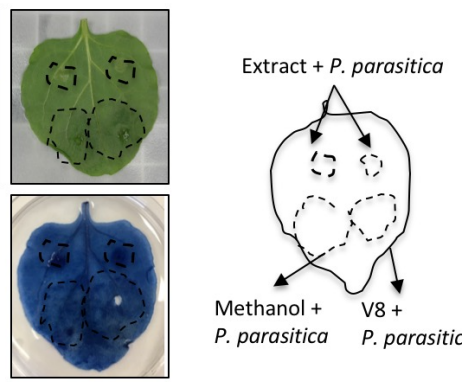

MOSEL-RD3 MOSEL-RD23

MOSEL-FLS1

MB322

\section{B}

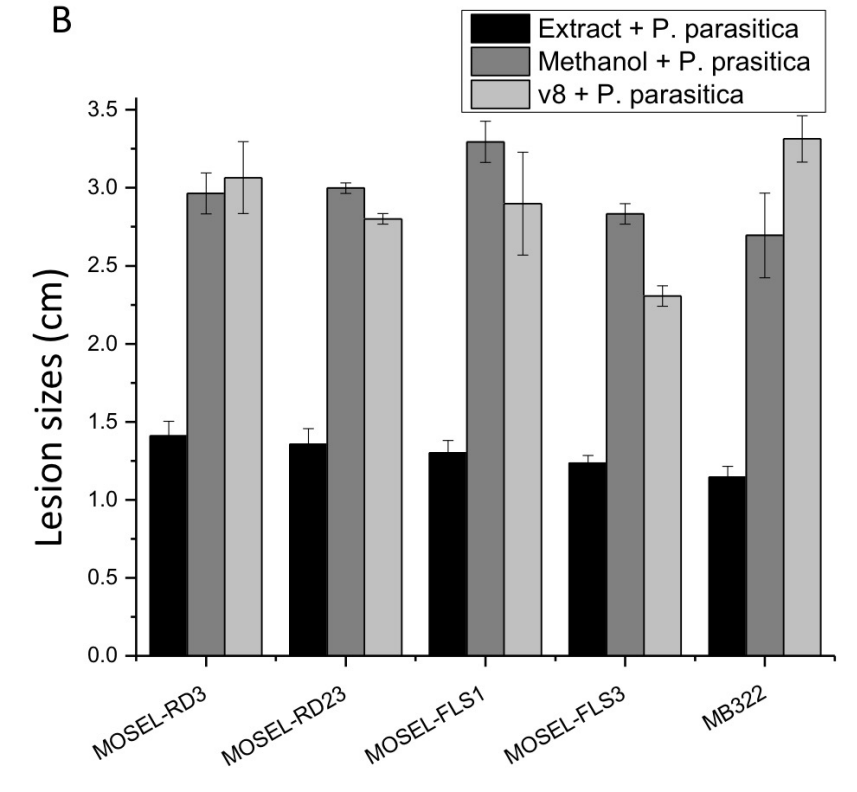

Figure 5. In vivo detached lead Bioactivity of $1 \%$ bacterial extracts against Phytophthora parasitica. (A) Detached leaf assay showing activity of bacterial extract of MOSEL-RD3, MOSEL-RD23, MOSEL-FLS1, MOSEL-FLS3 and MB322 on the growth of P. parasitica. (B) Bar graphs showing average lesion diameter caused by $P$. parasitica on tobacco leaves 


\section{A}

\begin{tabular}{lcr|}
$\mathrm{A}=95 \%\left(\mathrm{H}_{2} \mathrm{O}\right)$ & $\mathrm{A}=0 \%$ \\
\hline $\mathrm{B}=5 \%$ (Acetonitrile) & $80 \%$ & $\mathrm{~B}=100 \%$ \\
\hline $0 \mathrm{~min}$ & $10 \mathrm{~min}$ & $20 \mathrm{~min}$
\end{tabular}

B

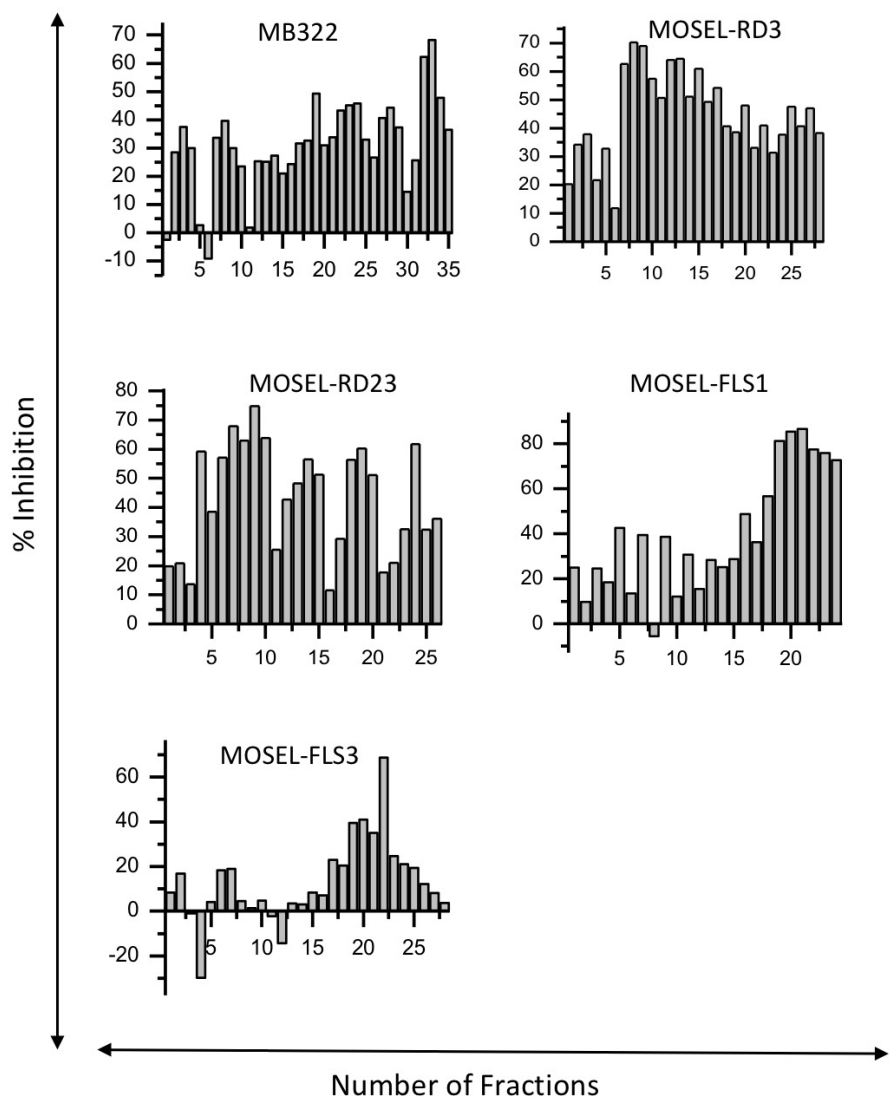

Figure 6. Bioactivity of fractions of the ethyl acetate extract from selected endophytic bacteria culture supernatant obtained through high-pressure liquid chromatography (HPLC) against $P$. parasitica 


\section{TABLES}

Table 1. Molecular identification of endophytic bacteria from different plants a) Dodonaea viscosa b) Fagonia indica c) Caralluma tuberculata and d) Calendula arvensis using 16S rRNA gene sequencing and anti-Phytophthora activity of bacterial extracts at different concentrations against Phytophthora parasitica

\begin{tabular}{|c|c|c|c|c|c|c|c|}
\hline \multirow[t]{2}{*}{ Strain ID } & \multirow[t]{2}{*}{ Source } & \multirow{2}{*}{$\begin{array}{l}\text { Top BLAST search } \\
\text { hit (NCBI) }\end{array}$} & \multirow{2}{*}{$\begin{array}{c}\% \mathbf{N t} \\
\text { identity }\end{array}$} & \multirow{2}{*}{$\begin{array}{c}\text { Disc } \\
\text { Diffusion } \\
\text { Method }\end{array}$} & \multicolumn{3}{|c|}{ \% Growth Inhibition } \\
\hline & & & & & $400 \mu \mathrm{g} / \mathrm{ml}$ & $40 \mu \mathrm{g} / \mathrm{ml}$ & $4 \mu \mathrm{g} / \mathrm{ml}$ \\
\hline MOSEL-RD3 & $\begin{array}{l}\text { Dodonaea } \\
\text { viscosa }\end{array}$ & $\begin{array}{l}\text { Streptomyces } \\
\text { alboniger }\end{array}$ & 100.0 & +++ & $91.96 \pm 0.70$ & $78.14 \pm 1.08$ & $4.12 \pm 1.07$ \\
\hline MOSEL-RD23 & $\begin{array}{l}\text { Dodonaea } \\
\text { viscosa }\end{array}$ & $\begin{array}{l}\text { Pseudomonas } \\
\text { taiwanensis }\end{array}$ & 100.0 & +++ & $92.11 \pm 1.38$ & $47.46 \pm 2.99$ & $9.96 \pm 1.79$ \\
\hline MOSEL-RD36 & $\begin{array}{l}\text { Dodonaea } \\
\text { viscosa }\end{array}$ & $\begin{array}{l}\text { Pseudomonas } \\
\text { geniculata }\end{array}$ & 100.0 & - & $80.54 \pm 0.53$ & $5.47 \pm 0.88$ & $3.74 \pm 0.61$ \\
\hline MOSEL-FLS1 & Fagonia indica & $\begin{array}{l}\text { Enterobacter } \\
\text { hormaechei }\end{array}$ & 100.0 & +++ & $98.76 \pm 0.08$ & $98.09 \pm 0.11$ & $34.49 \pm 0.88$ \\
\hline MOSEL-FLS3 & Fagonia indica & Bacillus tequilensis & 100.0 & +++ & $98.75 \pm 0.05$ & $98.27 \pm 0.05$ & $40.55 \pm 0.72$ \\
\hline MOSEL-FIL19 & Fagonia indica & Pantoea sp. & 95.0 & - & $82.05 \pm 0.72$ & $50.95 \pm 0.86$ & $7.2 \pm 0.80$ \\
\hline MOSEL-MIC5 & $\begin{array}{l}\text { Caralluma } \\
\text { tuberculata }\end{array}$ & Bacillus flexus & 100.0 & +++ & $93.93 \pm 0.08$ & $52.98 \pm 1.18$ & $8.36 \pm 1.35$ \\
\hline MOSEL-MIS12 & $\begin{array}{l}\text { Caralluma } \\
\text { tuberculata }\end{array}$ & $\begin{array}{l}\text { Pseudarthrobacter } \\
\text { phenanthrenivorans }\end{array}$ & 100.0 & - & $89.57 \pm 0.57$ & $76.53 \pm 0.57$ & $66.15 \pm 2.11$ \\
\hline MB322 & $\begin{array}{l}\text { Calendula } \\
\text { arvensis }\end{array}$ & Delftia lacustris & 93.60 & +++ & $92.32 \pm 1.03$ & $86.49 \pm 1.03$ & $34.38 \pm 1.41$ \\
\hline
\end{tabular}

